\title{
Human Resources Key Performance Indicators
}

\author{
Gabranová Iveta
}

\begin{abstract}
The article brings out a proposed strategy map and respective key performance indicators (KPIs) in human resources (HR). The article provides an overview of how HR activities are supported in order to reach the partial goals of HR as defined in the strategic map. Overall the aim of the paper is to show the possibilities of using the modern Balanced Scorecard method in human capital.
\end{abstract}

Key words: key performance indicators, entrepreneurial sector, HR scorecard, performance, Balanced Scorecard

\section{INTRODUCTION}

Many companies have implemented tools for measuring their performance in order to stay in business and come in contact with tough competition. Organizations must face not only to more demanding conditions but in the current period to the world financial crisis as well. Due to these reasons, the organizations are forced to measure performance of the organization and contribute to the stability of the organization in today's competitive environment. Organizations try to measure performance according to the financial drivers but in the recent period top leaders attempted to find new performance indicators which would take the "wind from sail" to their rivals in the market.

One of these competitive advantages is human capital. As the Tootell et al. (2009) stated "since 1980s there has been an increasing emphasis on the importance of HR measurement." Yeung and Berman (1997) declared that "HR measures should be impact rather than activity orientated, forward looking than backward looking, and should focus on the entire HR system not just on individual practices."

Toulson and Dawe (2004) identified three obstacles in measuring HR: lack of HR experience and precision and difficulties in measurement.

There were defined tools by various authors for measuring the HR capital. Srimannarayana (2010) brought brief overview of invented methods to evaluate HR capital:

- multiple constituency approach suggested by Tsui,

- human resources accounting system proposed by Flamholtz,

- McConnel identified 16 categories to be measured in HR,

- return of investment methodology investigated by Fitz-Enz,

- Ulrich has showed how HR practices relate to BSC through productivity, people and process indicators,

- methodology of behavioral costing to measure the financial impact to HR activities proposed by Cascio and Boundrenau,

- BSC in which strategic goals i.e. operational objectives are transfer into 4 perspectives. 
Based upon the model of BSC introduced by Kaplan and Norton (2007) and consequently its application in the area of the human resources, a new tool HR Scorecard for the management and measurement of the human capital was established. Becker, Huselid and Ulrich (2001) who have outlined HR Scorecard, added that it does two important things:

- manage HR as a strategic asset,

- demonstrate HR's contribution to firm's financial success.

Also Ulrich and Brockbank (2005) appended that strategic contribution accounts for almost half of HR's total influence on business performance. Norton (2009) made a key point about what differentiates the scorecard from other business performance measurement frameworks in the marketplace: "Many people will build a list of measurements that are non-financial and think that they have a balanced scorecard, but in our view the scorecard has to tell the story of company's strategy. The biggest mistake organizations make is that they think that scorecard is just about measurement." Huselid, Becker and Beatty (2005) also confirmed that the HR Scorecard is designed to guide management of the HR function. The essential part of the HR scorecard is the strategy map. Kaplan and Norton (1996) called the strategy map to represent the firm's value chain. These are diagrams of the value chain, such as those shown in figure 1.

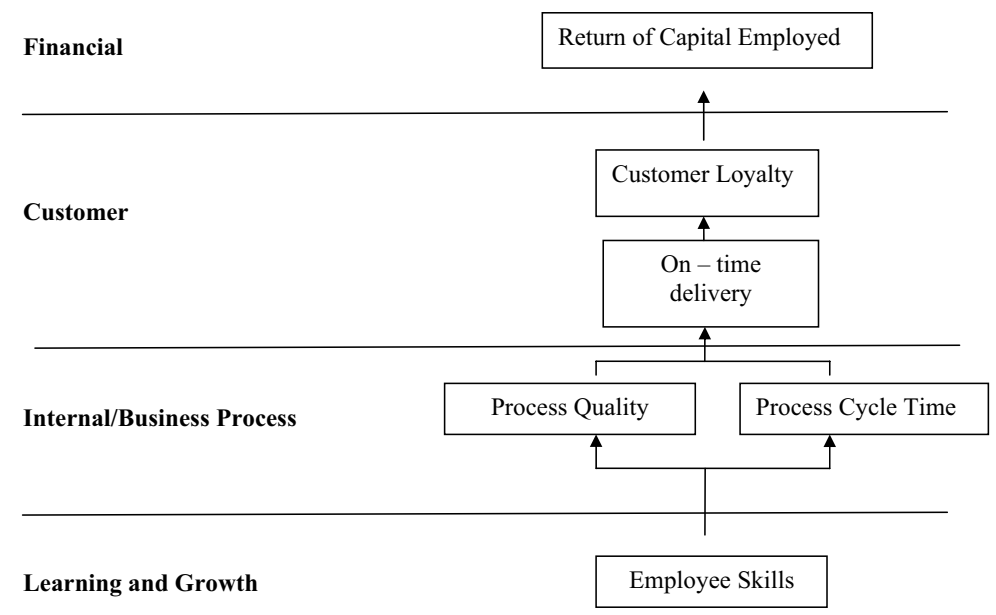

Fig.1 - A Simple Illustration of Value Creation. Source: Robert S. Kaplan and David P. Norton, The Balanced Scorecard.

Huselid, Becker and Beatty (2005) declared that the elements in the HR Scorecard are key leading indicators for workforce success. Key performance indicators are assigned to each perspective in strategy map and lately KPIs on HR level became significant benchmark in the entrepreneurial sector. Bean and Gerathy (2003) presented that according to their experience; KPIs are valid and effective when applied in a consistent and comprehensive manner. Further, they declare that financial performance must be respected as the critical measure of the success for every business but financial KPIs are closely related set of operational metrics i. e. on HR level, too. Bauer (2005) stated that once KPIs have been indentified, defined and formalized, 
business leaders may feel that KPI battle is won. Where possible, KPI targets must be based on concrete data and non-manipulative formulas. Griffin (2004) pointed out that there should be a direct link from KPIs to goals, from goals to objectives and from objectives to strategies. Skibniewski and Ghosh (2009) defined that all KPIs should impact a business decision in some time scale, depending on the window of time available. That makes the decision process difficult from the decisions made under no time constraint. Organizations should identify areas of business processes that are the most critical to the financial success of the organization. Further, KPIs can be divided into lagging and leading. Kaplan and Norton (2007) explained the difference between them. Leading indicator is a metric that mainly refers to future developments and drivers/causes. Lagging indicator is a metric that mainly refers to past developments and effects/results, e.g. reflects history and outcomes of certain actions and processes.

Bauer (2004) emphasized that one of the key concerns during implementation of KPIs is the ability to differentiate more important strategy-driven metrics from the plain vanilla metrics. Selection of the wrong metrics for KPIs can significantly damage or even submarine a performance management initiative. Eckerson (2007) in his paper claimed that metrics are powerful force that can drive change in an organization - but only if the right metrics are developed and applied. The wrong metrics can wreak havoc on an organization processes and demoralize employees. Further Eckerson (2007) described what characterizes "good” KPIs. According to his study effective KPIs are:

- Sparse: The fewer KPIs the better.

- Drillable: Users can drill into detail.

- Simple: Users understand the KPI.

- Actionable: Users know how to affect outcomes.

- Owned: KPIs have and owner.

- Referenced: Users can view origins and context.

- Correlated: KPIs drive desired outcomes.

- Balanced: KPIs consist of both financial and non-financial metrics.

- Aligned: KPIs don't undermine each other.

- Validated: Workers can't circumvent the KPIs.

On the other hand, Hursman (2010) defined next five criteria for effective KPIs:

- Specific

- Measurable

- Attainable

- Relevant

- Time bound

"S-M-A-R-T" is a fine way to spell KPIs, as this is a solid framework for making decisions about KPI selection. Anderson (2011) quoted Weller in his paper who presents the importance of KPIs uniquely: "If you don't measure and benchmark, you won't know how you are doing now, which areas of your process need the most attention, and how well your changes are working down the road." 
Hursman (2010) briefly characterized a process about establishing KPIs: Determine your corporate goals. Identify metrics to grade progress against those goals. Capture actual data for those metrics. Jam metrics into scorecards. Jam scorecards down throats of employees. Cronin (2007) declared other important issue regarding the KPIs. KPIs, both financial and non-financial, are critical element of effective communication of a company's progress towards its goals. Choosing relevant KPIs requires thinking to be aligned with the strategies and objectives; once this is done, the choice of measures of success is often obvious one. Further Cronin (2007) said that it is inappropriate to specify how many KPIs company should have - but his experience suggests that there is a key for most organizations between four and ten measures. Harvey (2000) confirmed that no matter which KPIs are used, they should mirror the business strategy and be reformulated periodically to adapt to the changing entrepreneurial environment. The priority for organizations is to use KPIs in a business context at all times, to measure customer and service margins, make effective business decisions and offer exciting customer propositions to drive business forward.

\section{METHODOLOGY}

The aim of an empirical study performed within organizations in Czech and Slovak republic was to indentified:

- Strategic targets.

- Partial goals and respective KPIs on HR level within BSC perspectives.

The research was performed during October 2010 in the companies in Czech and Slovak republic. The research was accomplished by structured interviews, which took 45 minutes in average, with 14 managers and also by collecting primary data. Data were gained by caring out the online questionnaire for the HR managers i.e. HR employees. The questions in questionnaire were formulated in order to provide validity, information value and thus contribute to the accomplishment of the defined goals. Questionnaire and related questions were divided into areas as follows:

1. Implementation of BSC on human resources management (HRM) level.

2. Definition of organizations' strategic goals and partial goals in each perspective in HR scorecard in HRM level.

3. Describing mutual connection among partial goals in frame of the strategy map.

4. Assigning used KPIs to each objective in the strategy map.

The target organizations for survey were chosen according to size of organization and number of employees where criterion was more than 100 employees. The reason why these criterions were defined was that there was presumption that the organization has experience with managing of human capital and had willingness to perform the interview as well. The online questionnaire was distributed via e - mail sending the direct link. After collecting data further analysis was carried out it means it requires the application of a quantitative approach due to the analysis of causal relations among individual variables. The qualitative research was also applied in order to comprehend the results. At the same time, induction was applied to analyze the results. Further the author's HR professional experience was applied for research and 
analysis of the results as well. The experience slightly influenced the results in way when the data were analyzed because author can demonstrated and evaluated whether the answers are substantive and have utilization in more organizations e.g. KPIs.

\section{HUMAN RESOURCE STRATEGY MAP}

During creating the strategy map and implementation of the KPIs, it is necessary to take into consideration the differences of each organization (e.g. organization structure, way of leading human capital,...). The CEO and other "C level" executives should take into account this fact from each perspective i.e. to develop feasible and effective method for improving the performance of the organization on HR level. Strategy map comprises essential part of HR scorecard. Developing the strategy map on the HR level, managers have to define clear, measurable and attainable targets which lead to the enhancement of efficiency of the organization. In each perspective of the HR scorecard i.e. in financial, customer, internal and learning and growth, the goals must be determined from HR attitude. Inseparable part of HR strategy map should not be orientation only on the profit or quality orientation but focus on orientation on the customer, because employees are tightly in touch with the customers e. g. deal with customer complaints, provide good customer service and information. Employees should always resolve problems quickly, efficiently and at the heart of customer service process. Further, top management should realize in which phase the organization is situated, it means in the beginning, in the expansion or in the depression. This is very necessary to consider due to the cost perspective. Creating the strategy map should also respect the external and internal HR factors influencing the organization performance. Another important fact linked to the strategy map is that executives should take into account the size achievement of the organization.

After research and consultations with HR leaders, goals of the organization are defined as follows:

- Preferred Employer i.e. be the employer of the 1st choice

- Cost optimization

- Profitability increase

- Customer orientation

Above mentioned targets can be reached by the implementation of the following strategy map on the HR level (figure 2): 


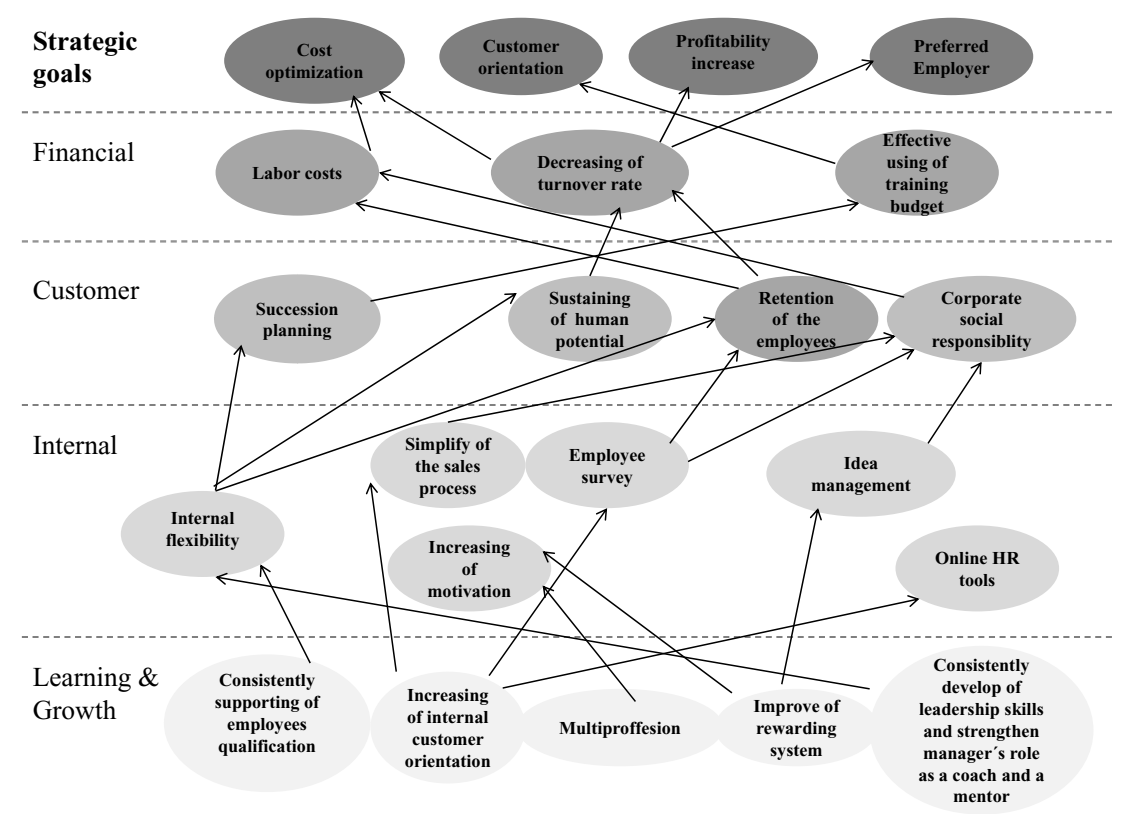

Fig. 2 - Proposal of the strategy map on HR level for organization. Source: own study

The strategy map was proposed and constructed according to results from research. Depicted strategic targets were presented the most in the answers and made the core for building it. Other partial goals in each perspective were responds on question: "Please specify the strategic goals in Learning and Growth (L\&G), Internal, Customer and Financial perspective in area of HRM?" Also HR professional experiences were used to judge well-founded manager's opinion and review if it is possible to apply in HRM. All supported targets defined in the L\&G perspective are directly linked to the next partial HR goals in each perspective.

Strategy map in $L \& G$ perspective can be divided into two parts.

First part which is tightly connected to HR processes and support process of continuous education on the one hand it brings other benefit as effective communication of corporate value on the other hand. There are included partial goals as: "consistently supporting of employees qualification, development of manager skills and sustaining multiskilled employees system."

All above mentioned partial targets are directly linked to the training system in the organization. Overall the training process in organization should serve as an individual motivation tool for employees and should be adjusted to the organization needs, mission, and strategy. Simultaneously it should respect following area:

- Customer orientation i.e. how to deal with arrogant customer, stressful situations or the best way how to handle with customer, be able to create win-win situation.

- Communication and promotion of sharing the organization values

- Strengthen of the internal relations

- Internal communication

- Teamwork 
Second part of strategy map is orientated on chain of organization's value creation it means what organization provides to our clients. It is essential to orientate on mutual commitment and need to use internal customer orientation with the aim to satisfy the external customer. This activity is "transfer" to partial target "increasing of internal customer orientation". Last target of strategy map in L\&G perspective - "rewarding system improvement" includes procedure centered on non-monetary motivator increasing the performance.

The verification of strategy map in practice will be part of further research and result will be get together in prepared case study.

Every partial goal in L\&G perspective should involve the action measures which sustain HR processes and thus enable to reach the strategic goals.

Table 1 depicts necessary steps to do and perform defined strategic targets.

Tab. 1 - HR activity how to reach the partial goals in L\&G perspective. Source: own study

\begin{tabular}{|l|l|}
\hline Partial goals & Support HR activities \\
\hline $\begin{array}{l}\text { Consistently supporting of employees } \\
\text { qualification }\end{array}$ & $\begin{array}{l}\text { Yearly employee dialogue } \\
\text { Cooperation with key universities } \\
\text { Internal "company academy" } \\
\text { Evaluation of training activity (qualification } \\
\text { index) }\end{array}$ \\
\hline $\begin{array}{l}\text { Increasing of internal customer orienta- } \\
\text { tion }\end{array}$ & $\begin{array}{l}\text { Strengthen of company culture } \\
\text { Determination of key processes } \\
\text { Cooperation and teamwork }\end{array}$ \\
\hline Multiprofession & $\begin{array}{l}\text { Determination of key posts } \\
\text { Talent project } \\
\text { Yearly employee dialogue } \\
\text { Job rotation project }\end{array}$ \\
\hline Motivation system improvement & $\begin{array}{l}\text { Non-monetary system } \\
\text { Performance rewarding system }\end{array}$ \\
\hline $\begin{array}{l}\text { Consistently develop of leadership skills } \\
\text { and strengthen manager's role as a } \\
\text { coach and a mentor }\end{array}$ & $\begin{array}{l}\text { Yearly employee dialogue } \\
\text { Support internal lectures } \\
\text { Continuous education of the business leaders }\end{array}$ \\
\hline
\end{tabular}

Chosen support HR activities should comprise essential part of HR policy. Yearly employee dialogue is not only an annual discussion about employee's performance in respective year but it should serve as a career planning tool that helps top leaders to manage the personal development and path career of employees. The tool should provide all necessary information about individual succession planning of employee, next development measures and review of the potential. By reviewing of employee's potential manager can find out who can be an internal lector or mentor in internal "company academy." Next vital part of this tool is agreement of individual goals between employee and supervisor which should be directly connected to a business target. This is also connected with the fact that companies use determination of in- 
dividual goals for employees in the full range in order to reach strategic goals of the company on one hand and has impact on performance rewarding system on the other hand. Performance rewarding system in organization should include targets orientated on the customer e. g. how many products have been sold per 1 months, customer "fluctuation rate" or fulfillment of strategic projects e. g. implementation of HR online tools. Rewarding performance system can be set as follows:

- $0 \%$ - goal was not reached,

- $50 \%$ - goal was reached partly,

- $100 \%$ goal was reached fully.

To all targets have to be assign measurable criteria e.g. deadline of implementation the projects.

Conducting of the employee dialogue has impact on almost all area of HR policy and corporate culture as well.

Table 2 shows mutual connection of partial goals among perspectives within the strategic goals.

Tab. 2 - Mutual connection among individual targets of each perspective. Source: own study

\begin{tabular}{|c|c|c|c|c|}
\hline $\begin{array}{c}\text { Learning \& } \\
\text { Growth }\end{array}$ & Internal & Customer & Financial & Strategic goals \\
\hline $\begin{array}{l}\text { Consistently } \\
\text { supporting } \\
\text { of employees } \\
\text { qualification }\end{array}$ & $\begin{array}{l}\text { Internal flex- } \\
\text { ibility }\end{array}$ & $\begin{array}{c}\text { Succession plan- } \\
\text { ning } \\
\text { Using of human } \\
\text { potential } \\
\text { Retention of the } \\
\text { employees }\end{array}$ & $\begin{array}{l}\text { Decreasing of } \\
\text { turnover rate }\end{array}$ & $\begin{array}{l}\text { Cost optimiza- } \\
\text { tion } \\
\text { Profitability } \\
\text { increase } \\
\text { Preferred Em- } \\
\text { ployer } \\
\end{array}$ \\
\hline $\begin{array}{c}\text { Increasing of in- } \\
\text { ternal customer } \\
\text { orientation }\end{array}$ & $\begin{array}{c}\text { Simplify sales } \\
\text { process } \\
\text { Employee } \\
\text { survey } \\
\text { Online HR } \\
\text { tools } \\
\end{array}$ & $\begin{array}{l}\text { Retention of the } \\
\text { employees } \\
\text { Corporate social } \\
\text { responsibility }\end{array}$ & $\begin{array}{l}\text { Labor costs } \\
\text { Effective using } \\
\text { of training } \\
\text { budget }\end{array}$ & $\begin{array}{l}\text { Cost optimiza- } \\
\text { tion } \\
\text { Profitability } \\
\text { increase } \\
\text { Customer orien- } \\
\text { tation } \\
\end{array}$ \\
\hline Multiprofession & $\begin{array}{l}\text { Increasing of } \\
\text { motivation }\end{array}$ & $\begin{array}{l}\text { Succession plan- } \\
\text { ning } \\
\text { Using of human } \\
\text { potential } \\
\text { Retention of the } \\
\text { employees }\end{array}$ & Labor costs & $\begin{array}{l}\text { Cost optimiza- } \\
\text { tion } \\
\text { Profitability } \\
\text { increase }\end{array}$ \\
\hline $\begin{array}{c}\text { Motivation } \\
\text { system improve- } \\
\text { ment }\end{array}$ & $\begin{array}{l}\text { Idea mana-ge- } \\
\text { ment }\end{array}$ & $\begin{array}{l}\text { Corporate social } \\
\text { responsibility }\end{array}$ & Labor costs & $\begin{array}{l}\text { Cost optimiza- } \\
\text { tion } \\
\text { Profitability } \\
\text { increase }\end{array}$ \\
\hline
\end{tabular}




\begin{tabular}{|c|c|c|c|c|}
\hline $\begin{array}{c}\text { Consistently } \\
\text { develop of } \\
\text { leadership skills } \\
\text { and strengthen } \\
\text { manager's role } \\
\text { as a coach and a } \\
\text { mentor }\end{array}$ & $\begin{array}{c}\text { Internal flex- } \\
\text { ibility }\end{array}$ & $\begin{array}{c}\text { Using of human } \\
\text { potential } \\
\text { Retention of the } \\
\text { employees }\end{array}$ & $\begin{array}{c}\text { Decreasing of } \\
\text { turnover rate }\end{array}$ & $\begin{array}{c}\text { Profitability } \\
\text { increase } \\
\text { tion } \\
\text { Preferred Em- } \\
\text { ployer }\end{array}$ \\
\hline
\end{tabular}

\section{KEY PERFORMANCE INDICATORS}

One of the steps of HR scorecard implementation is continuous monitoring and reporting of the defined partial targets i.e. strategic goals which are achieved. KPIs serve to follow this phase of implementation of HR scorecard.

KPIs have to be linked to all partial goals within the strategy map. It is essential to assign the required strategic value which will have expressing power about the level of organization performance. Table 3 points out lagging and leading KPIs which are related to the objectives from strategy map and are designed in order to reach the organization's long term approach in the entrepreneurial sector. Splitting the KPIs on lagging and leading were based on the impact on HR key processes in the organization. KPIs as a recruiting costs, qualification index, posts filled by internal sources or leadership index were put into leading one because the results of these indicators can influence the HRM for the future e.g. if the recruiting costs will be higher and higher it is necessary to change the selection process of the employees, used selection tools and has big impact on the motivating system as well. Qualification index it means number of employees who increased their qualification necessary to perform their job and leadership index i.e. number of employees who passed the leadership entry program and are ready to take leading position have importance in leading KPIs as well due to impact on the future leading of human potential. Qualification index is tightly connected to multiskilled employees because when employees increase their qualification they are able to occupy two positions on one hand and at the same time organization has personal successors on all positions on the other hand. The big advantage of the personal successors system is that organization can run in normal mode when some employee suddenly quits the job.

Tab. 3 - Overview of KPIs on HR level. Source: own study

\begin{tabular}{|c|c|c|c|}
\hline & Objectives & Lagging KPIs & Leading KPIs \\
\hline \multirow{3}{*}{ 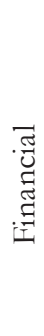 } & F1 - Labor costs & $\begin{array}{l}\text { Sickness rate } \\
\text { Labor cost per } 1 \text { employee }\end{array}$ & Productivity \\
\hline & $\begin{array}{l}\text { F2 - Decreasing of turno- } \\
\text { ver rate }\end{array}$ & $\%$ of turnover & Recruiting costs \\
\hline & $\begin{array}{l}\text { F3 - Effective using of } \\
\text { training budget }\end{array}$ & ROI of training & $\begin{array}{l}\text { Efficiency of investment to } \\
\text { human capital }\end{array}$ \\
\hline
\end{tabular}




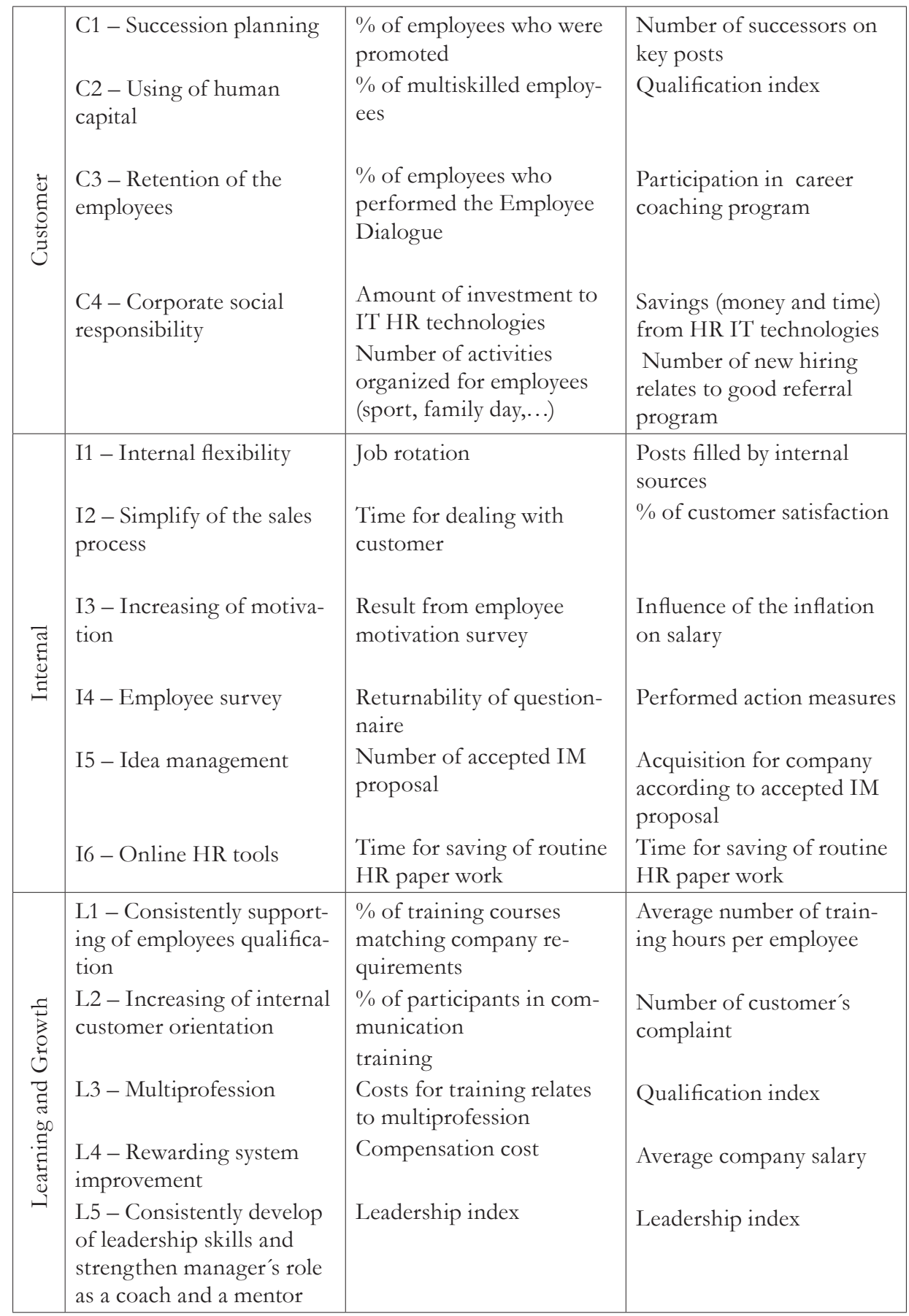




\section{DISCUSSION}

Implementation of HR scorecard brings required results if all business leaders continuously keep an eye on all HR processes.

Strategy map is proposed in HR level so it takes into consideration only HR processes i.e. HR mission. Learning and Growth, Internal and Customer perspectives are related to the employees i.e. human capital. The financial perspective shows the final impact from all above mentioned perspectives in the financial area of the organization.

The setting of appropriate KPIs on HR level is not so easy and sometimes it can take longer as the management presents. Top leaders should take into account all organization aspects it means financial situation, market position and also the vision of the company. The base for setting proper KPIs is formulating the strategy map and understanding the consequences between human resources management and significant company's targets.

Further next fundamental step for applicable KPIs is relevant partial goal in Learning and Growth perspective. Creation of the partial targets can be time consuming but it is necessary to pay attention to it. Consequent evaluation of the results has its importance due to the application of possible changes during the implementation and thus it makes organization more competitive and flexible.

Essential process of the implementation i.e. sustaining the positive development of HR strategy is the continual performed of the HR activities and HR action plan and measures e.g. arisen out of employee survey. In the beginning, company doesn't have to define many HR activities. Key of the HR success is not to underestimate it.

\section{CONCLUSION}

Key performance indicators present mirror of the organization performance. Management in the entrepreneurial sector has many KPIs to choose but all of chosen KPIs must be connected to HR mission i.e. vision. The goal of presented research is to find and set the KPIs on HR level according to defined HR strategy and targets. The research also presented the strategy map which is a necessary part of the HR scorecard and serves as a base for specifying the KPIs. Next it has been scientifically proven and according to $\mathrm{HR}$ experience in production plant, in general, implementation of HR scorecard has same rules and steps among organizations in frame of entrepreneurial environment e. g. in business companies or in financial houses. Main aim of all organization should be to have a manageable and sustainable HR scorecard with visible and measurable KPIs. Provided KPIs include all possible aspects - internal and external - to HR strategy with aim to reach higher organization approach. However, continuous improvement in organization development can be supported by high level of organization culture which means better communication and stronger team work.

\section{References}

1. Anderson, K. (2011). Metrics pave the path to world class.[online]. Managing accounts payable. ISSN 1080-5753. Retrieved from: http://web.ebscohost.com/ehost/pdfviewer/pdfviewer? vid=7\&hid=11\&sid=a294ed 98 -abe3 $-4394-8 \mathrm{cf0} 0$-ab8353d1d74c\% $\%$ sessionmgr12

2. Bauer, K. (2004). The Power of metrics - KPIs: Not all metrics are created equal. DM Review, 14 (12), 1-3. 
3. Bauer, K. (2005). KPIs: Avoiding the Threshold McGuffins. DM Review, 15 (4), 1-4. 4

4. Bean, C. \& Geraghty, K. (2003). Navigating the road to KPI success. Focus, 5(6), 37-41.

5. Becker, B. E., Huselid, M. A. \& Ulrich, D. (2001). The HR scorecard: linking people, strategy and performance. Boston: Harvard Business School Press.

6. Cronin, G. (2007). Measuring strategic progress. Choosing and using KPIs. Accountancy Ireland, 39 (4), 30 -31.

7. Eckerson, W.W. (2009). Performance Management Strategies. Business Intelligence Journal, 14(1), 24-27.

8. Fitz-Enz, J. (2009). The ROI of human capital: measuring the economic value of employee performance. New York: Amacon.

9. Griffin, J. (2004). Developing strategic KPIs for your BPM system. DM Review, 14 (10), 70.

10. Harvey, J. (2005). KPIs - The Broader strategic context. Credit Control, 26 (4), 65-66.

11. Huselid, M. A., Becker, B. E. \& Beatty, R. (2005). The workforce scorecard. Boston: Harvard Business School Press.

12. Hursman, A. (2010). Measure what matters. [online]. Information management. Retrieved from: http://web.ebscohost.com/ehost/pdfviewer/pdfviewer?vid=48\&hid=11\&sid=a294ed98abe3-4394-8cf0-ab8353d1d74c\%40sessionmgr12

13. Kaplan, S. R. \& Norton, D. P. (2007). Balanced Scorecard: Strategický systém mèréní výkonnosti podniku. Praha: Management Press.

14. Kaplan, S. R. \& Norton, D. P. (1996). The Balanced Scorecard. Boston: MA: Harvard Business School Press.

15. Skibniewski, M. J. \& Ghosh, S. (2009). Determination of Key Performance Indicators with Enterprise Resource Planning Systems in Engineering Construction Firms. Journal of Construction Engineering and Management, 135 (10), 965-978. http://dx.doi.org/10.1061/(ASCE)07339364(2009)135:10(965)

16. Srimannarayana, M. (2010). Status of HR measurement in India. VISION - The journal of business perspective, 14 (4), 295-307.

17. Tootell, B., Blackler, M., Toulson, P. \& Dewe, P. (2009). Metrics: HRM's Holy Grail? A New Zealand case study. Human Resources Management Journal, 19(4), 375-392. http://dx.doi. $\operatorname{org} / 10.1111 / j .1748-8583.2009 .00108 . x$

18. Toulson, P. \& Dewe,P. (2004). HR accounting as a measurement tool. Human Resource Management, 14 (2), 75-90. http://dx.doi.org/10.1111/j.1748-8583.2004.tb00120.x

19. Ulrich, D. \& Brockbank, W. (2005). The HR value proposition. Massachusetts: Harvard Business School Publishing.

20. Yeung, A.K. \& Berman,B. (1997). Adding value through human resources: reorienting human resources measurement to drive business performance. Human Resource Management, 36 (3), 321-335. http://dx.doi.org/10.1002/(SICI)1099-050X(199723)36:3<321::AIDHRM4>3.3.CO;2-2

\section{Contact information}

Ing. Iveta Gabčanová

Tomas Bata University in Zlin, Faculty of Management and Economics

Mostni 5139, 76001 Zlin

Tel: +421904653411

E-mail:ivetagabcanova@gmail.com

JEL Classification: M12 